\title{
Influence of Different Concentrations of Glycerol and Guar- xanthan on Properties of Pumpkin Oil Cake-Zein Bi-layer Film
}

\author{
Sandra Bulut* · Vera Lazić · Senka Popović · Nevena Hromiš · Danijela Šuput \\ University of Novi Sad, Faculty of Technology, Bulevar cara Lazara 1, 21000 Novi Sad, Serbia
}

\begin{abstract}
Summary: The objective of this study was to examine influence of glycerol and guar-xanthan in different concentrations on bi-layer film based on pumpkin oil cake (PuOC) and corn zein, and to find optimal concentrations of these additives which result in film with optimal mechanical and barrier characteristics. Different concentrations of glycerol $(30 \%, 40 \%$, and $50 \%)$ as plasticizer and guar-xanthan $(0.1 \%, 0.3 \%$, and $0.5 \%)$ as a stabilizer were added in PuOC layer, while zein layer stayed unchanged in all film compositions. Obtained results showed that the optimal mechanical properties had film with the lowest concentration of glycerol $(30 \%)$ and the highest concentration of guarxanthan $(0.5 \%)$. Films showed poor barrier for water vapour, typical for biopolymer-based films. However, all tested films were very good barrier to $\mathrm{O}_{2}$ (transmission rate lower than $50 \mathrm{ml} / \mathrm{m}^{2} /$ day at $1 \mathrm{bar}$ ). On the other hand, with increase of concentration of added substances, transmission rate of $\mathrm{CO}_{2}$ increased.

Key words: biopolymers, pumpkin oil cake, additives, bi-layer films, properties
\end{abstract}

\section{Introduction}

The ability to decompose in environment, as well as the fact that they are isolated from natural sources, makes biopolymers one of the most interesting topics for researchers in different fields of their possible applications. Today, biopolymers have wide application in pharmacy, medicine, agro and food industry. In recent years, there has been a great interest in biopolymers obtained from agro-industrial waste. Due to their chemical composition (proteins, polysaccharides and lipids), agro-industrial by-products, present a real potential in the production of environmentally friendly plastic (Lazić \& Novaković, 2010; Lazić \& Popović, 2015).

Pumpkin oil cake (PuOC) is a by-product, obtained after cold-pressing oil extraction from pumpkin seed. PuOC contains the least-processed form of pumpkin seed protein having approximate composition 63\%

\section{Corresponding author:}

sbulut@uns.ac.rs

Acknowledgement:

This study was presented at the joint International Bioscience Conference (IBSC) and the 6th International PSU - UNS Bioscience Conference held at the University of Novi Sad on 19-21 September 2016. The study is part of the project III 46010 "Novel encapsulation and enzyme technologies for a design of new biocatalysts and biologically active compounds aiming at enhancement of food quality, safety and competitiveness", financed by the Ministry for Education, Science and Technological Development of the Republic of Serbia. proteins, $12 \%$ carbohydrates, $4.5 \%$ crude fibers, $8.4 \%$ oils and $13 \%$ other components (Peričin et al., 2007). Popović et al. (2011) produced biodegradable films based on PuOC that showed good mechanical and gas barrier characteristics. However, in order to produce biodegradable pouches, these films were ineffective in forming heat seal under different conditions of heat time and pressure (Popović et al., 2015). To enable heat sealing of this promising materials, zein layer was casted as second layer on dried PuOC film (Popović et al., 2015).

Zein is the major storage protein of corn and comprises approximately $45-50 \%$ of the protein in corn. Zein can form tough, glossy, hydrophobic, greaseproof coatings that are resistant to microbial attack, with excellent flexibility and compressibility. One of the most promising applications of zein appears to be for biodegradable films and plastics used for packaging (Shukla \& Cheryan, 2001; Ghasnbarzadeh \& Orromiehi, 2009; Pol et al., 2002).

However, without addition of plasticizers, stabilizers and other additives, obtained biopolymerbased films are, usually, very rigid and not handable.

Plasticizers are small molecular-weight, hydrophilic, non-volatile substances that can be added to bio-based films and improve their flexibility and mechanical properties (Embuscado \& Huber, 2009; Skurtys et al., 2010). Plasticizers affect intermolecular interactions between polymer chains by reducing the strength of intermolecular forces and, in this way, increase elasticity. 
Common plasticizers used in edible films and coatings are typically polyols, including glycerol, propylene glycol, polypropylene glycol, sorbitol and sucrose, with water being the most efficient plasticizer. Fatty acids have also been used as plasticizers in edible films and coatings, though they are not as common (Embuscado \& Huber, 2009). Glycerol is plasticizer with the widest application due to its stability and compatibility with hydrophilic biopolymer chains (Fernandez-Cervera et al., 2004; Souza et al., 2013).

Guar-xanthan has been used as a stabilizer in starch -based biofilms in order to improve mechanical properties of polysaccharide biofilms. Xanthan gum is an extracellular polysaccharide obtained by aerobic fermentation of Xanthomonas campestris. It has wide application in the food industry due to its ability to form viscous solutions at very low concentrations (Šuput et al., 2016). Beside xanthan gum, wide application also has guar gum with similar characteristics (Suput et al., 2016). Guar gum acts as a thickening agent and stabilizer, helps maintaining structural homogeneity and functions as a binder (Šuput et al., 2016).

Although, addition of different additives can improve the flexibility and mechanical properties of biodegradable films, studies have shown that these additives can also have unwanted influence on some characteristics of films, especially on barrier properties. That is why it is very important to examine effect of appropriate plasticizers, stabilizers and other film's additives and find their concentration for obtaining films with optimal performance for packaging of different food products with specific requirements.

The objective of this study was to examine influence of two additives in different concentrations on bi-layer film properties, and find optimal concentration of these additives that give film with best mechanical and barrier characteristics.

\section{Materials and Methods}

The grounded hull-less pumpkin (Cucurbita pepo L. 'Olinka') oil cake (PuOC) was stored at the temperature of $4^{\circ} \mathrm{C}$. Other reagents used in this study were: glycerol (99.5\%); guar-xanthan, zein, polyethylene glycol (PEG), ethanol (85\%), and $\mathrm{NaOH}$.

\section{Preparation of bi-layer films}

The film-forming suspension of PuOC $(10 \%$, w/w) in deionized water was produced with addition of glycerol $(30 \%, 40 \%$, or $50 \%$ per weight of PuOC) and guar-xanthan $(0.1 \%, 0.3 \%$, or $0.5 \%$ per weight of polysaccharides in $\mathrm{PuOC}$ ). After adjusting $\mathrm{pH}=12$ using $0.2 \mathrm{M} \mathrm{NaOH}$, and incubating at $90^{\circ} \mathrm{C}$ for $20 \mathrm{~min}$ and then filtrated through nylon filtrate, solutions were casted onto Teflon-coated Petri dishes and films were dried for 2 days at room conditions $\left(23 \pm 2{ }^{\circ} \mathrm{C}, 50 \pm 5 \%\right.$ $\mathrm{RH})$.

The film-forming solution of zein (Z) $(10 \% \mathrm{w} / \mathrm{v})$ was prepared by suspending zein in $85 \%$ ethanol with the addition of PEG $400(50 \% \mathrm{w} / \mathrm{w}$, per weight of zein), and incubating solution at $80^{\circ} \mathrm{C}$. Zein solution was casted on dried PuOC films for obtaining composite bi-layer PuOC-Z films.

\section{Film properties}

\section{Thickness}

Film thickness was measured with a micrometer (Digico 1, Tesa, Swiss Made, Renens, Switzerland), with a sensitivity of $0.001 \mathrm{~mm}$. The results were expressed as the mean of at least ten measurements on each film, from which an average was obtained.

\section{Mechanical properties}

Tensile strength (TS, MPa) and elongation at break (EB, \%) of films were measured on an Instron Universal Testing Instrument Model No 4301 (Instron Engineering Corp., Canton, MA), according to the ASTM standard method D882-01.

The rectangular film strips of $80 \mathrm{~mm}$ in length and $15 \mathrm{~mm}$ in width were used. The initial grip separation was set at $50 \mathrm{~mm}$, and crosshead speed was set at 50 $\mathrm{mm} / \mathrm{min}$. Tensile strength and elongation at break for each type of film was repeated at least three times, from which an average was obtained.

\section{Physico-chemical properties}

Total soluble matter, moisture content and swelling of films were determined according to Hromiš et al. (2015). At least three measurements were conducted and average values were calculated with standard deviation (SD).

\section{Barrier properties}

The water vapour transmission rate (WVTR) was determined by the gravimetric method according to the standard ISO 2528:1995 (E). The used test conditions were: temperature $25^{\circ} \mathrm{C} \pm 1{ }^{\circ} \mathrm{C}$; relative humidity $90 \% \pm$ $2 \%$.

Determination of gas transmission rate $\left(\mathrm{CO}_{2}, \mathrm{~N}_{2}, \mathrm{O}_{2}\right)$ was conducted in accordance with using isostatic gaschromatographic method (DIN 53380, 1969), with the use of the Lyssy GPM-200 apparatus with the belonging Gasukuro Kogyo GC-320 gas chromatograph and the HP $3396 \mathrm{~A}$ integrator.

The investigations were performed at $23^{\circ} \mathrm{C}$ and 1 bar pressure difference, and volume of sample (gas) injected was $0.8 \mathrm{ml}$. The results of transmission rate determination are expressed in $\mathrm{ml} / \mathrm{m}^{2} /$ day at 1 bar pressure difference.

\section{Results and Discussion}

\section{Thickness}

Tested films had thickness from $0.26 \mathrm{~mm}$ to 0.33 $\mathrm{mm}$. Slight increase of film average thickness was observed with increase of glycerol concentrations, for 
the same concentrations of guar-xanthan. However, with increase of guar-xanthan concentration, for the same concentration of glycerol, slight decrease of film average thickness was obtained (Figure 1). Regardless of these slight differences, obtained results for thickness of all tested films were approximate $0.30 \mathrm{~mm} \pm 10 \%$.

\section{Mechanical properties}

Mechanical properties - tensile strength (TS) and elongation at break (EB), of produced films are presented in figure 2.

The optimal mechanical properties, namely highest values for TS and EB, were determined for the film with $30 \%$ of glycerol and $0.5 \%$ of guar-xanthan. Obtained results showed that higher concentrations of glycerol (above 30\%) led to decrease in TS end EB and formation of weak films. This is especially expressed for $\mathrm{EB}$, where the films with minimum concentration of glycerol $(30 \%)$ showed up to 5 times higher values than films with higher content of glycerol. Tapia-Blácido, Sobral and Menegalli (2005) obtained similar results. They examined the effect of drying temperature, relative humidity and concentration of glycerol on the mechanical properties of films based on Amaranth flour, and results showed that optimal mechanical properties could be obtained for similar conditions to the ones used in this experiment and $30 \%$ of glycerol concentrations $(\mathrm{g} / \mathrm{g}$ dry matter). Maximal tested concentration of guar-xanthan $(0.5 \%)$ gave films with highest TS as well as EB.

\section{Physico-chemical properties}

Physico-chemical properties of obtained films, such as moisture content, degree of swelling and total soluble matter, are presented in Figure 3. Obtained results are typical for biodegradable films, which, due to their hydrophilic nature, are very sensitive to moisture (Falguera et al., 2011; Han, 2014).

An increase of concentrations of guar-xanthan and glycerol had slight influence on increase of moisture content, as well as degree of swelling of films, while influence on total soluble matter wasn't detected.

With increase of plasticizers concentration, due to their hydrophilicity, films probably absorb higher amount of water (Cho et al., 2002). Addition of hydrophilic substances, such as plasticizers, may also increase the degree of swelling of biodegradable films (Kavoosi et al., 2013).

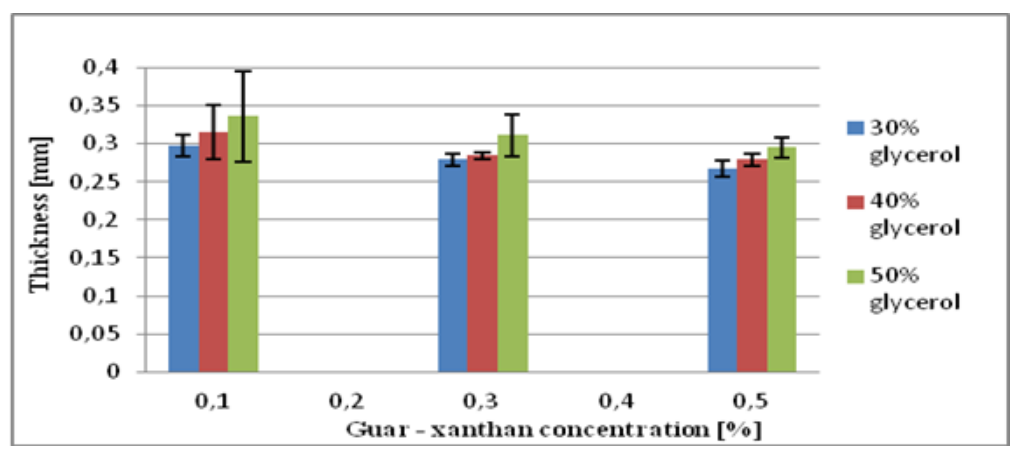

Figure 1. Thickness of obtained films

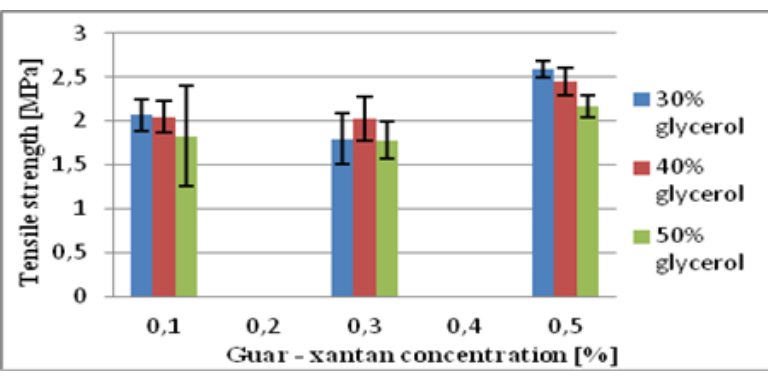

(a)

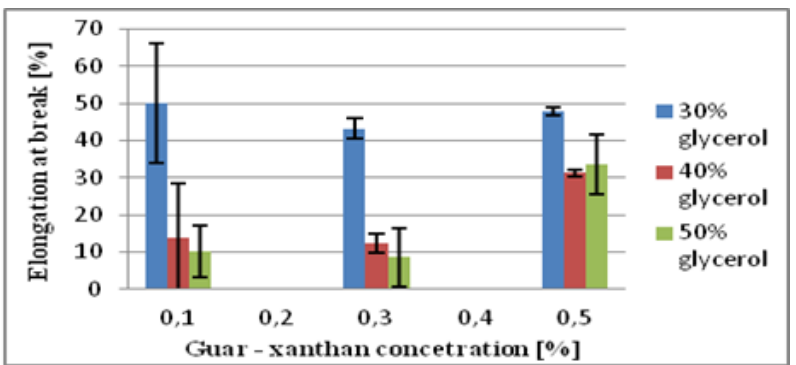

(b)

Figure 2. Mechanical properties of obtained films - (a) tensile strength (TS) and (b) elongation at break (EB) 


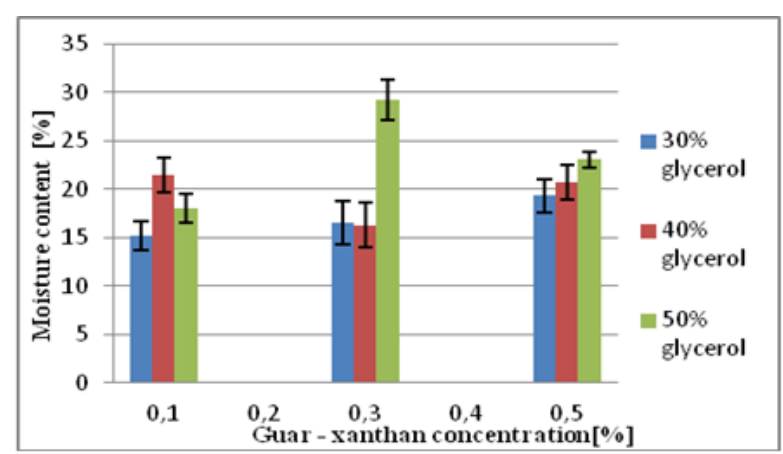

(a)

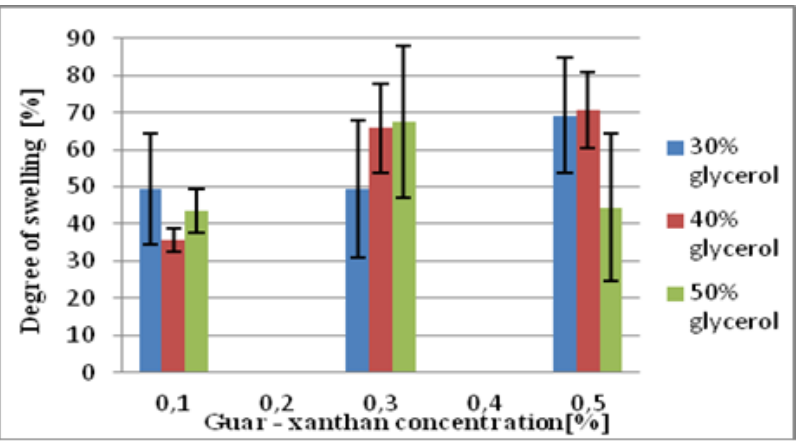

(b)

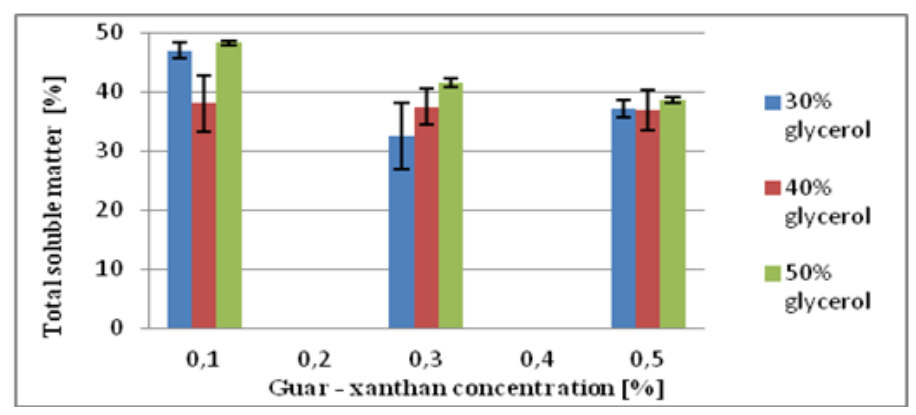

(c)

Figure 3. Physico-chemical properties of obtained films - (a) moisture content, (b) degree of swelling and (c) total soluble matter

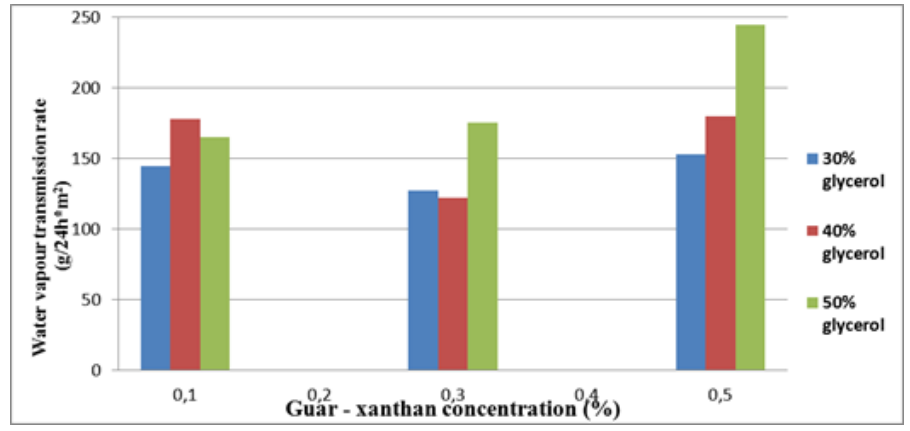

Figure 4. Water vapour transmission rate of obtained films

\section{Barrier properties}

Barrier properties, water vapor and gas transmission rate, are presented in Figures 4 and 5, respectively. Addition of selected additives had influence, not only on the mechanical properties, but also on barrier properties of obtained films. When WVTR is analysed, it can be seen that addition of highest concentrations of both additives, glycerol and guar-xanthan, led to increased WVTR $\left(244.76 \mathrm{~g} / 24 \mathrm{~h} \mathrm{~m}^{2}\right)$, while all other films showed WVTR in the range of $(121.88 \div 180.22)$ $\mathrm{g} / 24 \mathrm{~h} \mathrm{~m} \mathrm{~m}^{2}$.

Incorporation of plasticizers may increase hydrophilicity of films, and, in this way, also increases WVTR (Chang et al., 2000; Wiles et al., 2000). Šuput et al. (2016) showed that incorporation of glycerol and guar-xanthan into starch-based films, also had negative effect on WVTR, increasing obtained values for starch films.

Gas transmission rate of tested films is presented in Figure 5. The results showed that all obtained films had very good barrier properties to $\mathrm{O}_{2}$ (transmission rate lower than $50 \mathrm{ml} / \mathrm{m}^{2} /$ day at 1 bar), regardless of concentrations of glycerol and guar-xanthan. Meanwhile, an increase of $\mathrm{CO}_{2}$ transmission rate was observed with an increase of glycerol and guar-xanthan concentration. Results are in accordance with Popović et al. (2011) who produced biodegradable films based on PuOC $(0.25 \mathrm{~g} / \mathrm{g}$ $\mathrm{PuOC}$ of glycerol and without addition of guar-xanthan), and those films had very good gas barrier to $\mathrm{O}_{2}(12.1 \mathrm{ml} /$ $\mathrm{m}^{2} /$ day at 1 bar $)$ and $\mathrm{CO}_{2}\left(42.2 \mathrm{ml} / \mathrm{m}^{2} /\right.$ day at 1 bar $)$. 


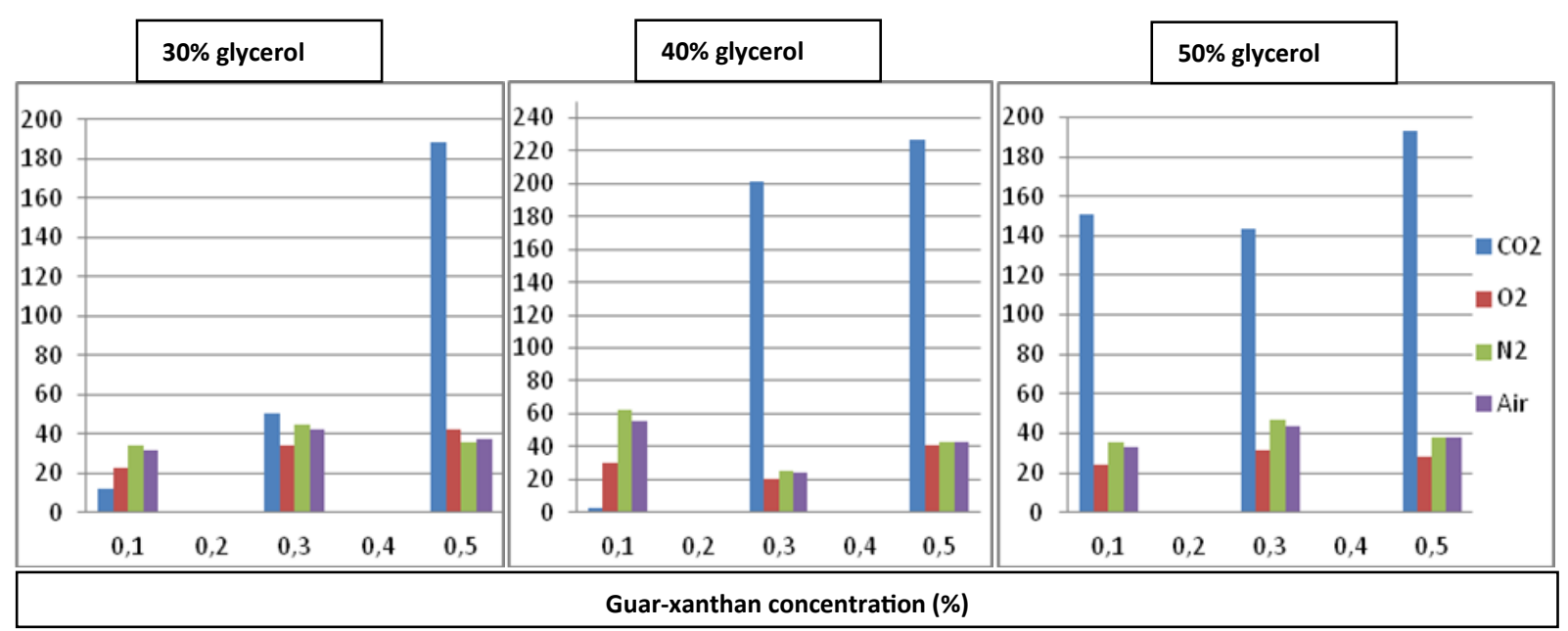

Figure 5. Gas transmission rate of obtained films

\section{Conclusion}

Obtained results showed that the optimal mechanical properties had film with the lowest concentration of glycerol and the highest concentration of guar-xanthan. Obtained values for moisture content, degree of swelling and total soluble matter are typical for biopolymer-based films and incorporated additives had minimal influence on these properties. Water vapour transmission rate of bi-layer film was altered only for highest concentrations of both additives. All tested films showed very good barrier to $\mathrm{O}_{2}$, which is one of the main require for food packing materials especially for very perishable products. With an increase of concentration of added substances, transmission rate of $\mathrm{CO}_{2}$ also increased. Presence of $\mathrm{CO}_{2}$ in packing may have an important role for maintaining the quality and extending the shelf-life of foods. However, for products for which process of respiration is characteristic, such as cheese, fresh fruits and vegetables, materials with higher transmission rate of $\mathrm{CO}_{2}$ can be advantageous.

\section{References}

ASTM. (2001). Standard test method for tensile properties of thin plastic sheeting. Annual book of ASTM standards. Designation D882-01. Philadelphia: ASTM, American Society for Testing Materials.

Chang, Y.P., Cheah, P.B. \& Seow, C.C. (2000). Plasticizingantiplasticizing effect of water on physical properties of tapioca starch films in the glassy state. Journal of Food Science, 65, 445-451.

Cho, S.Y., Park, J.W. \& Rhee, C. (2002). Properties of laminated films from whey powder and sodium caseinate mixtures and zein layers. LWT - Food Science and Technology, 35(2), 135-139.

DIN 53380. (1969). Prüfung Kunstoffolien, Elastomerfolien, Bestimmung der Gasdurchlässigkeit.

Embuscado, M.E. \& Huber, K.C. (2009). Edible films and coatings for food applications. Ed. Embuscado \& Huber, Springer Science+Business Media, LLC.
Falguera, V., Quinterob, J.P., Jimenez, A., Munoz, J.A. \& Ibarz, A. (2011). Edible films and coatings: Structures, active functions and trends in their use. Trends in Food Science \& Technology, 22, 292 -303 .

Fernandez-Cervera, M. Karjalainen, M. Airaksinen, S. Rantanen, J. Krogars, K. Heinamaki, J. Iraizoz Colarte, A. \& Yliruusi, J. (2004). Physical stability and moisture sorption of aqueous chitosan-amylose starch films plasticized with polyols. European Journal of Pharmaceutics and Biopharmaceutics, 58, 69-76.

Ghasnbarzadeh, B. \& Orromiehi, A.R. (2009). Thermal and mechanical behaviour of laminated protein films. Journal of Food Engineering, 90(4), 517-524.

Han, J.H. (2014). Innovations in food packaging. USA: Elsevier, Academic Press.

Hromiš, N., Lazić, V., Markov, S., Vaštag, Ž., Popović, S., Šuput, D., Džinić, N., Velićanski, A. \& Popović, Lj. (2015). Optimization of chitosan biofilm properties by addition of caraway essential oil and beeswax. Journal of Food Engineering, 158, 86-93.

ISO 2528 (1995). Sheet materials -Determination of water vapour transmission rate - Gravimetric (dish) method. Switzerland: International Organisation for Standardisation.

Kavoosi, G., Dadfar, S.M.M. \& Mohammadi Purfard, A. (2013). Mechanical, physical, antioxidant, and antimicrobial properties of gelatin films incorporated with Thymol for potential use as nano wound dressing. Journal of Food Science, 78, E244-E250.

Lazić, V. \& Novaković, D. (2010). Ambalaža i životna sredina. Serbia, Novi Sad: Faculty of Technology.

Lazić, V. \& Popović, S. (2015). Biorazgradivi ambalažni materijali. Serbia, Novi Sad: Faculty of Technology.

Peričin, D., Radulović, Lj., Mađarev, S., \& Dimić, E. (2007). Bioprocess for value added products from oil cakes. Journal of Edible Oil Industry, 38, 35-40.

Pol, H., Dawson, P., Acton, J. \& Ogale, A. (2002). Soy protein isolate/corn zein laminated films: transport and mechanical properties. Journal of Food Science, 67, 212-217.

Popović, S., Peričin, D., Vaštag, Ž., Popović, Lj. \& Lazić, V. (2011). Evaluation of edible film-forming ability of pumpkin oil cake; effect of $\mathrm{pH}$ and temperature. Food Hydrocolloid, 25(3), 470-476.

Popović, S., Popović, S., Lazić, V., Hromiš, N., Šuput, D. \& Popović, Lj. (2015). Evaluation of biopolymer pouches application for vegetable oil protection. Annals of Nutrition and Metabolism, 67, 542-543.

Shukla, R. \& Cheryan, M. (2001). Zein: the industrial protein from corn. Industrial Crops and Products 13, 171-192. 
Skurtys O., Acevedo C., Pedreschi F., Enrione J., Osorio F. \& Aguilera J.M. (2010). Food bydrocolloid edible films and coatings. NewYork: Nova Science Publishers Inc.

Souza, A.C., Goto, G.E.O., Mainardi, J.A., Coelho, A.C.V. \& Tadini, C.C. (2013). Cassava starch composite films incorporated with cinnamon essential oil: Antimicrobial activity, microstructure, mechanical and barrier properties. Food Science Technology, 54, 346352.

Šuput, D., Lazić, V., Pezo, L., Popović, S., Hromiš, N. \& Bulut, S. (2016). The effects of glycerol and guar-xanthan mixture on mechanical and barrier properties of starch based edible films chemometric analysis. Hemijska Industrija, DOI:10.2298/ HEMIND150819010S.

Tapia-Blácido, D., Sobral, P.J. \& Menegalli, F.C. (2005). Effects of drying temperature and relative humidity on the mechanical properties of amaranth flour films plasticized with glycerol. Brazilian Journal of Chemical Engineering, 22, 249-256.

Wiles, J.L., Vergano, P.J., Barron, F.H., Bunn, J.M. \& Testin, R.F. (2000). Water vapour transmission rates and sorption behaviour of chitosan films. Journal of Food Science, 65, 1175-1179.

\section{Uticaj različite koncentracije glicerola i guar-ksantana na osobine dvoslojnog filma na bazi pogače uljane tikve golice i kukuruznog zeina}

\section{Sandra Bulut · Vera Lazić · Senka Popović · Nevena Hromiš · Danijela Šuput}

Sažetak: Cilj ovog rada je da se ispita uticaj različite koncentracije glicerola i guar-ksantana na osobine dvoslojnog filma na bazi pogače uljane tikve golice (PuOC) i kukuruznog zeina, kao i da se pronađe optimalna koncentracija ovih aditiva koja će dati filmove sa najboljim mehaničkim i barijernim osobinama. Različite koncentracije glicerola $(30 \%$, $40 \%$ i $50 \%)$ i guar-ksantana $(0,1 \%, 0,3 \%$ i $0,5 \%)$ su dodate u PuOC sloj, dok je sastav zeinskog sloja ostao nepromenjen. Dobijeni rezultati pokazuju da najbolje mehaničke osobine ima film sa najmanjom koncentracijom glicerola (30\%) i najvećom koncentracijom guar-ksantana (0,5\%). Filmovi su pokazali lošiju barijeru prema vodenoj pari, a dobijene vrednosti su tipične za biopolimerne filmove. Međutim, svi ispitivani filmovi su pokazali veoma dobru barijeru za $\mathrm{O}_{2}$ (brzina propustljivosti manja od $50 \mathrm{ml} / \mathrm{m}^{2} /$ danu na 1 bar). Sa druge strane, sa povećanjem koncentracije dodatih aditiva, došlo je do povećanja brzine propustljivosti $\mathrm{CO}_{2}$.

Ključne reči: biopolimeri, pogača uljane tikve, aditivi, dvoslojni filmovi, osobine 